\title{
Anti-Inflammatory Properties of Drugs Used to Control COVID-19 and their Effects on the Renin-Angiotensin System and Angiotensin-Converting Enzyme-2
}

\author{
Hamed Gilzad Kohan ${ }^{1}$, Fakhreddin Jamali ${ }^{2}$
}

${ }^{1}$ Western New England University, College of Pharmacy \& Health Sciences, Springfield, MA, USA; ${ }^{2}$ Faculty of Pharmacy and Pharmaceutical Sciences, University Of Alberta, Edmonton, Canada

Received, July 15, 2020, Revised, July 30, 2020; Accepted, July 30, 2020, Published, August 1, 2020

\begin{abstract}
COVID-19 infection is associated with systemic inflammation, and sometimes hyperinflammatory responses with cytokine storm. This plays a major role in COVID-19 severity and poor disease prognosis, even death. Higher levels of inflammatory hallmarks including C-reactive protein, ferritin, D-dimers, and cytokines such as interleukin (IL) -6, IL-10 and tumor necrosis factor- $\alpha$ (TNF- $\alpha$ ) have been reported. Many anti-viral drugs have been tried, but none were proven fully effective. Supportive care and management of the complications that are caused mainly by inflammation might be the key to greater survival rates and shorter hospitalization (e.g., the use of remdesivir, lopinavir, ritonavir, umifenovir (arbidol), oseltamivir, ganciclovir, favipiravir, darunavir, hydroxychloroquine, chloroquine, colchicine, azithromycin, anakinra, canakinumab, tocilizumab, siltuximab, sarilumab, Type 1 interferon, interferon $\beta-1$ a, interferon $\alpha$ $2 \mathrm{~b}$, baricitinib, ruxolitinib, fedratinib, methylprednisolone and dexamethasone). However, the efficacy of these treatments still needs well-planned clinical trials. In such trials, careful attention must be paid to the duration of the treatment, the onset of beneficial effects, and the severity of the disease, otherwise, the outcomes may still remain inconclusive. Herein, we present a review of the current drugs, which are being used in the management of the disease and their anti-inflammatory properties. We also investigated if these drugs directly interact with Angiotensin-Converting Enzyme (ACE 2), which is a crucial component of the virus entry to the cells.
\end{abstract}

\section{INTRODUCTION}

The coronavirus disease 2019 (COVID-19) is a viral infection caused by a new $\beta$-coronavirus, severe acute respiratory syndrome coronavirus 2 (SARS-CoV-2) which is an enveloped nonsegmented positive-sense RNA virus (1-4).

COVID-19 is an acute respiratory infectious disease, which primarily spreads through the respiratory tract $(3,5,6)$. The virus can be transmitted through the spread of droplets from patients to others or oral-fecal route (7-9). The common clinical symptoms of COVID-19 infection include cough and fever as the dominant symptoms, shortness of breath, fatigue, increased sputum production, sore throat, and headache. Additionally, up to 5 percent of the patients show gastrointestinal symptoms including diarrhea and vomiting (10-14).

In most cases, patients who develop acute respiratory distress syndrome are elderly patients or those with underlying disorders such as hypertension, chronic obstructive pulmonary disease, diabetes, and cardiovascular complications. Other symptoms include septic shock, metabolic acidosis, and coagulation dysfunction, which may lead to death (11-16).

Covid-19 infection is associated with systemic inflammation, as do other infections. It has been shown that in several viral infections such as hepatitis $\mathrm{C}$ virus, HIV, hepatitis B virus, influenza virus, and severe acute respiratory syndrome virus (SARS-CoV), inflammation exists and levels of

Corresponding Authors: Hamed Gilzad Kohan. Western New England University, College of Pharmacy \& Health Sciences, Springfield, MA, USA, 01119 email:hamed.gilzadkohan@wne.edu, or Fakreddin Jamali, Faculty of Pharmacy and Pharmaceutical Sciences, University Of Alberta, Edmonton, Canada, T6G 2E1; fjamali@ualberta.ca. 
ABBREVIATION - ACE 2, Angiotensin-Converting Enzyme II; AT, Angiotensin receptor; COVID-19, coronavirus disease 2019; CRS, cytokine release syndrome; FDA, the U.F, Food and Drug Administration; GCSF, granulocyte colonystimulating factor; IL, interleukin; HIV, human immunodeficiency viruses; ICU, intensive care unit; IP-10, interferon-gamma-induced protein; JAK, Janus Kinase; MCP-1, monocyte chemoattractant protein-1; MIP-1 $\alpha$, macrophage inflammatory protein 1- $\alpha$; RAS, Renin-Angiotensin System; SARS-CoV-2, severe acute respiratory syndrome coronavirus 2; TNF- $\alpha$, tumor necrosis factor- $\alpha$

interleukin (IL) -6 and tumor necrosis factor- $\alpha$ (TNF- $\alpha$ ) are increased (17-19). The laboratory results indicate that in most COVID-19 patients white blood cell count is normal or decreased, and lymphocytopenia exists $(12-14,16)$. In severe cases, the neutrophil count, D-dimer, blood urea, and creatinine levels are significantly higher than normal ranges, and the lymphocyte counts decrease. Moreover, inflammatory biomarkers such as IL-6, IL-10 and TNF- $\alpha$ ) increase in COVID-19 patients, which is an indication of the inflammation associated with COVID-19 (12, 2022). The ICU patients also had higher plasma levels of IL-2, IL-7, IL-10, granulocyte colonystimulating factor (GCSF), $10 \mathrm{kD}$ interferongamma-induced protein (IP-10), monocyte chemoattractant protein-1 (MCP-1), macrophage inflammatory protein 1- $\alpha$ (MIP-1 $\alpha$ ) (4). The hypersecretion of the cytokines, also known as "cytokine storm", is associated with the disease severity (21, 23-25). Additionally, it has been reported that the $\mathrm{C}$ reactive protein (CRP), a commonly used inflammatory marker in clinical practice, is significantly higher in severe cases of COVID-19 as compared to non-severe cases (26).

Several studies have already published to frame how hyperinflammatory responses, which resemble the cytokine release syndrome (CRS), play a major role in COVID-19 severity and usually associated with poor disease prognosis (21, 23-25). Higher levels of inflammatory hallmarks including C-reactive protein, ferritin, D-dimers, and cytokines such as IL-6, IL-10, and TNF- $\alpha$ consistently occur in patients with CRS $(4,26,27)$.

In general, inflammation is a fundamental and protective reaction of the body to infections and injuries, which has very complex and diverse patterns and has a significant role in the development of various diseases $(28,29)$. There are two types of inflammatory responses, acute and chronic. During acute inflammation, leukocytes infiltrate the damaged region to remove the stimulus and repair the tissue. This process results in healing in a short time. On the other hand, chronic inflammation is a prolonged and dysregulated process, which involves active inflammation and tissue destruction. Chronic inflammation is associated with many pathophysiological conditions such as atherosclerosis, cancer, arthritis, and autoimmune diseases (29). Inflammation often is associated with altered expression of metabolizing enzymes, transporters, receptors, and plasma proteins (30).

In some cases, the immune response that is triggered by SARS-CoV-2 goes out of control so that it may lead to pulmonary tissue damage, functional impairment, and reduced lung capacity (31). Although much of the attention has been paid to pulmonary complications, it is important to also focus on other pathophysiological aspects of COVID-19 such as cardiovascular complications. Cardiovascular events associated with COVID-19 are significant contributors to the mortality of the disease and include but not limited to myocardial injury and myocarditis, acute myocardial infarction, acute heart failure and cardiomyopathy, dysrhythmias (32-34), and thromboembolic events (35). Most of these complications are due to severe systemic inflammation that increases the risk of cardiovascular or other organ complications (22, 32). Arguably, female patients may be more tolerant of the complication of COVID-19 infection due to the anti-inflammatory actions of estrogen (36).

In addition, SARS-CoV-2 enters the lung alveolar epithelial cells through a receptormediated endocytosis mechanism. The virus utilizes the angiotensin-converting enzyme II (ACE2) as the entry receptor. The spike (S) protein of SARS-CoV-2 binds to Angiotensin-Converting Enzyme II (ACE 2), which leads to virus entry to the host cell. The virus uses the cellular protease 
TMPRSS2 (transmembrane protease serine 2) for priming the spike protein and its activation (37-39).

The Renin-Angiotensin System (RAS) regulates human physiology and controls cardiovascular homeostasis. The RAS exerts its effects through its components, the angiotensinconverting enzyme (ACE) and ACE2, their angiotensin (Ang) products (Ang II and Ang1-7), Ang II receptor type 1 (AT1R) and type 2 (AT2R) and G-coupled protein receptor of Ang1-7, Mas receptor. ACE metabolizes Ang I to Ang II which binds with AT1R and AT2R. RAS consists of two opposing arms. The first arm, ACE, Ang II, and AT1R causes inflammation, vasoconstriction, cell proliferation, and fibrosis. The second arm is antiinflammatory, antifibrotic, antiproliferative, and a vasodilator. It consists of ACE2, Ang1-7, and Mas receptor An imbalance of RAS components changes the system's role from a regulator to a harmful one (40-42). Inflammation causes such an imbalance $(30,43,44)$, and being an inflammatory condition, COVID-19 seems to do the same (45).

To treat COVID-19 patients, various pharmacological interventions are suggested. The evidence to support beneficial effects is, however, mainly questionable (46). This review was carried out to test the hypothesis that the majority of drugs proposed to treat COVID-19 are anti-inflammatory in nature. Currently, there are no Food and Drug Administration (FDA)-approved drugs for the treatment of COVID-19, although remdesivir, which is an investigational antiviral drug is available through an FDA emergency use authorization (47-50). Other antiviral drugs such as a combination of lopinavir and ritonavir $(47,51$, $52)$ and favipiravir $(47,53)$ have been also used in the treatment of COVID-19. However, in all cases, the FDA panel recommended against using them because solid clinical trial data are absent or no significant clinical benefit has been observed in patients with COVID-19.

\section{METHODS}

\section{Search and selection strategy \\ Initial serch to identify the drug classes in the treatment of COVID-19}

Since there are overwhelming number of the publications in regards to the treatment of COVID19 , initially we conducted a search to identify the drug classes which are mostly used in the treatment of the disease. The search was conducted using keywords "COVID-19" AND "Treatment" OR "Management" OR "Drug class" in PubMed and ScienceDirect databases and the US clinical trials registry (https://clinicaltrials.gov/ and https://www.covid19treatmentguidelines.nih.gov/ whats-new/). The initial search helped us to identify our keywords for step 1 . For articles not in English, we used the web version of the Google Translate (https://translate.google.com/)

\section{Step 1: identification of the drugs used in the treatment of COVID-19}

We search for medications used to treat COVID-19 patients during January 1, to July 14, 2020 under the class of drugs identified in the initial search using the mentioned databases. Keywords consisted of "COVID-19" AND each of the following terms: "antiviral treatment", "macrolide", "antimalarial", "interleukin-1 (IL-1) inhibitor", "interleukin-6 (IL-6) inhibitor", "interferon treatment", "Janus Kinase (JAK) inhibitor", and "corticosteroid therapy". After trying several different combinations, the search keywords were selected among different possible combinations to find the most relevant results. Moreover, missing publications were identified by going through the reference lists of the selected articles. The articles that studied the current pharmacological options for the treatment of COVID-19 were selected for this review. Duplicates were excluded from the search results. For reporting the step 1 results, the name and category of the drugs, main therapeutic use, the mechanism(s) of action for the main therapeutic use, and references were presented. Figure 1 summarizes the study selection design for step 1 .

\section{Step 2: reviewing the anti-inflammatory properties of the drugs identified in step 1 and their possible effect on ACE2}

We searched each drug, which was identified in step one for their anti-inflammatory properties and their possible effect on activation or inhibition of the ACE2. PubMed and ScienceDirect databases were selected as the search tools. Keywords for the 
search included "The name of the drug identified in step 1" AND "anti-inflammatory" or "The name of the drug identified in step 1" AND "ACE 2". The search conducted without any language or time restriction to identify the maximum number of published studies. Moreover, missing publications were identified by going through the reference lists of the selected articles. Duplicates were excluded from the search results.

\section{RESULTS}

From our initial search the following keywords was selected for the main serch in step 1: "COVID-19" AND each of the following terms: "antiviral treatment", "macrolide", "antimalarial", “interleukin-1 (IL-1) inhibitor”, “interleukin-6 (IL6) inhibitor", "interferon treatment", "Janus Kinase (JAK) inhibitor", and "corticosteroid therapy".

In total, 1066 articles were found and screened and among those, 62 were selected based on the inclusion criteria (Figure 1).

Table 1 lists the drugs, which were identified as the current or potential pharmacotherapies for the treatment/management of COVID-19.

With the exception of a few, drugs used in treating COVID-19 infection have either direct or indirect anti-inflammatory actions (Table 2).

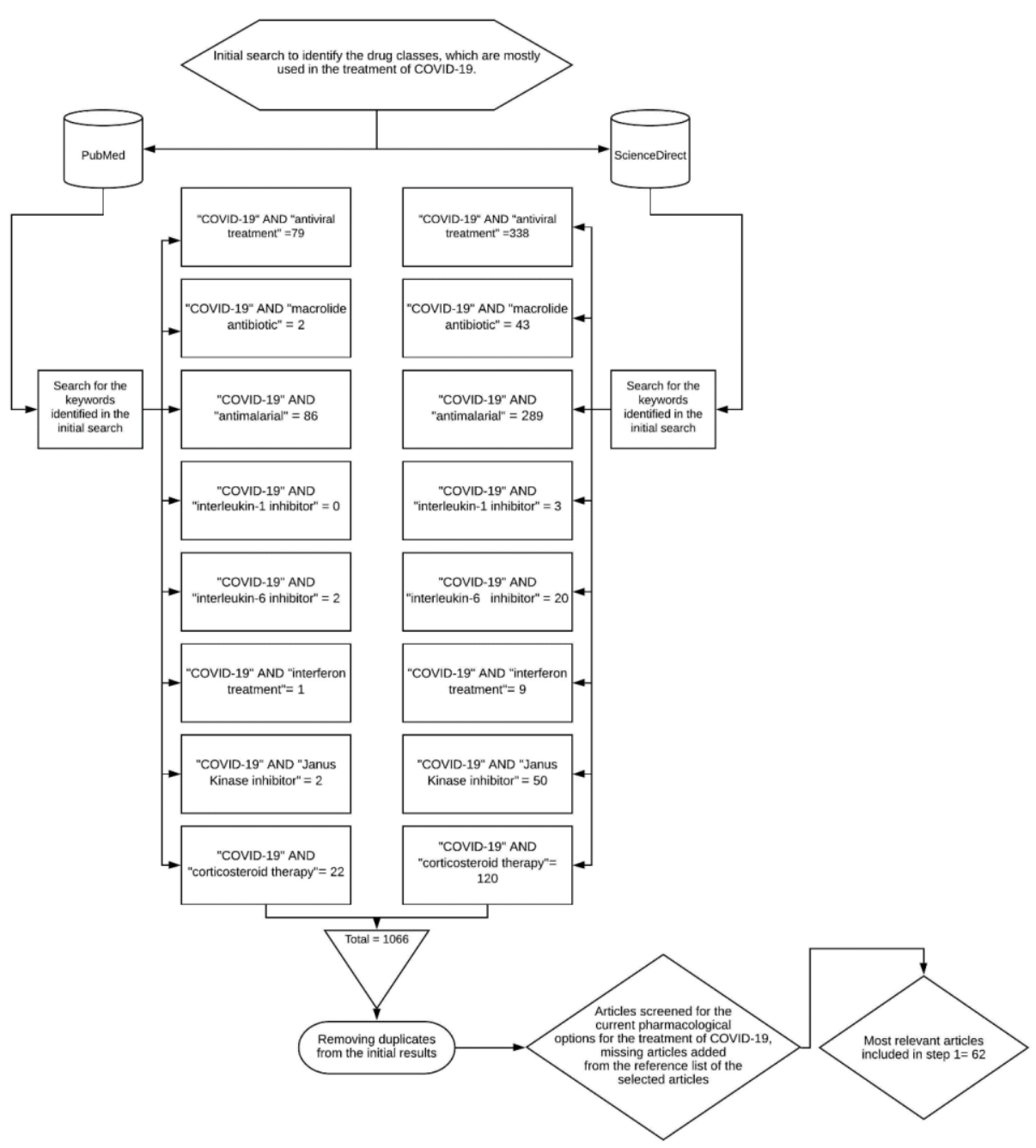

Figure 1. Summary of the study design for step 1. 
Table 1. Drugs used to treat COVID-19 infection

\begin{tabular}{|c|c|c|c|}
\hline Drug & Main use & $\begin{array}{l}\text { Mechanism(s) of action for } \\
\text { the main therapeutic use }\end{array}$ & Reference(s) \\
\hline Remdesivir & Antiviral & $\begin{array}{l}\text { Adenosine nucleotide } \\
\text { prodrug }\end{array}$ & $(47-50,54-58)$ \\
\hline Lopinavir, ritonavir & Antiviral & Protease inhibitor & $\begin{array}{l}(47,48,51 \\
52,59-61)\end{array}$ \\
\hline $\begin{array}{l}\text { umifenovir (arbidol), } \\
\text { oseltamivir, and } \\
\text { ganciclovir }\end{array}$ & Antiviral & $\begin{array}{l}\text { Umifenovir inhibits } \\
\text { membrane fusion. } \\
\text { Oseltamivir is a } \\
\text { neuraminidase inhibitor. } \\
\text { Ribavirin is a nucleoside } \\
\text { inhibitor and a polymerase } \\
\text { inhibitor. Ganciclovir inhibits } \\
\text { viral DNA polymerase }\end{array}$ & $(56,61)$ \\
\hline Favipiravir & Antiviral & $\begin{array}{l}\text { Selective inhibition of viral } \\
\text { RNA-dependent RNA } \\
\text { polymerase. }\end{array}$ & (53) \\
\hline Darunavir & Antiviral & Protease inhibitor & $(62)$ \\
\hline $\begin{array}{l}\text { Hydroxychloroquine, } \\
\text { chloroquine }\end{array}$ & $\begin{array}{l}\text { Anti-malaria agent. } \\
\text { Immunomodulator to treat } \\
\text { autoimmune diseases such } \\
\text { as systemic lupus } \\
\text { erythematosus (SLE) and } \\
\text { rheumatoid arthritis }\end{array}$ & $\begin{array}{l}\text { Exact antimalarial } \\
\text { mechanism of action is } \\
\text { unknown, possibly by raising } \\
\text { intracellular } \mathrm{pH} \text {, and, } \\
\text { affecting the endosomal } \\
\text { activity }\end{array}$ & $(58,63-71)$ \\
\hline Colchicine & $\begin{array}{l}\text { Gout, Familial } \\
\text { Mediterranean Fever }\end{array}$ & $\begin{array}{l}\text { Colchicine modulates } \\
\text { multiple pro- and } \\
\text { antiinflammatory pathways } \\
\text { associated with gouty } \\
\text { arthritis, including prevention } \\
\text { of microtubule assembly, } \\
\text { which in turn disrupts the } \\
\text { inflammasome activation, } \\
\text { microtubule-based } \\
\text { inflammatory cell } \\
\text { chemotaxis, generation of } \\
\text { leukotrienes and cytokines, } \\
\text { and phagocytosis }\end{array}$ & $(72-74)$ \\
\hline Azithromycin & Macrolide antibiotic & $\begin{array}{l}\text { Binds to } 50 \mathrm{~S} \text { ribosomal } \\
\text { subunit of microorganisms }\end{array}$ & $\begin{array}{l}(58,65,71 \\
75,76)\end{array}$ \\
\hline Anakinra & Rheumatoid arthritis & Interleukin-1 inhibitor & $(55,77,78)$ \\
\hline Canakinumab & $\begin{array}{l}\text { Cryopyrin-associated } \\
\text { periodic syndromes }\end{array}$ & Interleukin-1 inhibitor & (79) \\
\hline Tocilizumab & $\begin{array}{l}\text { Rheumatoid arthritis, } \\
\text { cytokine release syndrome }\end{array}$ & Interleukin-6 inhibitor & $(80-86)$ \\
\hline Siltuximab & Castleman Disease & Interleukin-6 inhibitor & $(80,87,88)$ \\
\hline Sarilumab & Rheumatoid arthritis & Interleukin-6 inhibitor & $(58,89,90)$ \\
\hline
\end{tabular}




\section{Table 1, Cont'd}

\begin{tabular}{|c|c|c|c|}
\hline $\begin{array}{l}\text { Type } 1 \text { interferon } \\
\text { (IFN-I), mainly } \\
\text { Interferon } \beta-1 \mathrm{a} \text {, and } \\
\text { Interferon } \alpha-2 \mathrm{~b}\end{array}$ & $\begin{array}{l}\text { Multiple Sclerosis, } \\
\text { hepatitis B/C, hairy cell } \\
\text { leukemia melanoma }\end{array}$ & $\begin{array}{l}\text { Interferon binds to interferon } \\
\text { receptors. Immunomodulator }\end{array}$ & $\begin{array}{l}(56,57,61 \\
91-94)\end{array}$ \\
\hline Baricitinib & Rheumatoid arthritis & Janus Kinase inhibitor & $(54,57,95-99)$ \\
\hline Ruxolitinib & Myelofibrosis & Janus kinase inhibitor & $(54,100-102)$ \\
\hline Fedratinib & Myelofibrosis & Janus kinase inhibitor & (103) \\
\hline Methylprednisolone & $\begin{array}{l}\text { Several, including allergic } \\
\text { conditions, acute } \\
\text { exacerbation of multiple } \\
\text { sclerosis, acute spinal cord } \\
\text { injury }\end{array}$ & Corticosteroid & $(58,104-106)$ \\
\hline Dexamethasone & $\begin{array}{l}\text { Several, including general } \\
\text { inflammation, acute } \\
\text { exacerbation of multiple } \\
\text { sclerosis, cerebral edema, } \\
\text { shock, allergic conditions }\end{array}$ & Corticosteroid & $\begin{array}{l}(25,54,59, \\
107,108)\end{array}$ \\
\hline
\end{tabular}

Table 2. Anti-inflammatory properties of the drugs used in the treatment of COVID-19 and their potential mechanisms.

\begin{tabular}{|c|c|c|}
\hline Drug & Direct or indirect Anti-inflammatory effect & $\begin{array}{l}\text { Direct effect or } \\
\text { interaction } \\
\text { with ACE } 2 \\
\end{array}$ \\
\hline Remdesivir & Indirect $^{1}$ & Indirect $^{2}$ \\
\hline Lopinavir, ritonavir & Indirect $^{1}$ & Indirect $^{2}$ \\
\hline $\begin{array}{l}\text { Umifenovir (arbidol), } \\
\text { interferon, } \\
\text { oseltamivir, ribavirin, } \\
\text { and ganciclovir }\end{array}$ & $\begin{array}{l}\text { Indirect }{ }^{1} \text {, also oseltamivir prophylaxis may reduce } \\
\text { inflammation and facilitate cross-strain protective T cell } \\
\text { memory to influenza virus (109). Anti-inflammatory effect of } \\
\text { macromolecular pro-drugs of ribavirin is attributed to the } \\
\text { polymer bckbone of the pro-drugs, not the drug aloane } \\
(110) \text {. }\end{array}$ & Indirect $^{2}$ \\
\hline Favipiravir & Indirect $^{1}$ & Indirect $^{2}$ \\
\hline Darunavir & Indirect $^{1}$ & Indirect $^{2}$ \\
\hline $\begin{array}{l}\text { Hydroxychloroquine, } \\
\text { Chloroquine }\end{array}$ & $\begin{array}{l}\text { Direct. Inhibition of IL-1-alpha production by monocytes and } \\
\text { IL-6 production by T cells and monocyte Inhibition of the } \\
\text { alkaline cytosolic lysophospholipase and phospholipase A } \\
\text { inhibition of T and B-cell receptors calcium signaling, } \\
\text { inhibits toll-like receptors signaling, and inhibition of tumor } \\
\text { necrosis factor (TNF)-alpha production }(68,111-124) \text {. }\end{array}$ & $\begin{array}{l}\text { May prevent the } \\
\text { viral S protein } \\
\text { from binding to } \\
\text { a newly } \\
\text { discovered } \\
\text { ganglioside- } \\
\text { binding domain, }\end{array}$ \\
\hline
\end{tabular}


Table 2, Cont'd

Colchicine

Azithromycin

Anakinra

Canakinumab

Tocilizumab

Siltuximab

Sarilumab

Interferon $\beta-1 \mathrm{a}$, Interferon $\alpha-2 b$

Baricitinib

Ruxolitinib

Fedratinib

Methylprednisolone
Direct. Distruption the cytoskeletal functions through inhibition of $\beta$-tubulin polymerization into microtubules, which in turn prevents activation, degranulation, and migration of neutrophils. It may interfere with intracellular assembly of inflammasome complex in neutrophils and monocytes, which mediates the activation of interleukin- $1 \beta$ (125-127).

Direct. Reducing the expression of iNOS and the proinflammatory macrophage receptor (CCR7) and polarizing Macrophages to an M2 Phenotype by Inhibition of the STAT1 and NF- $\mathrm{BB}$ signaling pathways. Interactions with cytosolic phospholipase A 2 ( $\left.\mathrm{cPLA}_{2}\right)$ results in inhibiting $\mathrm{PGE}_{2}$, IL-6, IL-12p40, and arachidonic acid release, increased endocytosis and/or expression of Toll- like receptor (TLR)2, TLR4, and TLR9 in dendritic cells (DCs), inhibition of production of pro-inflammatory cytokines - such as IL-8, IL-6, TNF alpha, and MMPs (128-132).

Direct. Interleukin-1 receptor antagonist (133).

Direct. Interleukin-1 receptor antagonist (134-137).

Direct. Interleukin-6 receptor antagonist (138-142).

Direct. Interleukin-6 receptor antagonist $(140,142,143)$.

Direct. Interleukin-6 receptor antagonist (144-146).

Direct. Binding to specific receptors on the cell membrane and trigger the JAK-STAT signaling pathway. Enhance macrophage, cytotoxic $\mathrm{T}$ cell, and natural killer cell activity $(118,147-154)$.

Direct. Inhibitor of the Janus kinases (155-159).

Direct. Inhibitor of the Janus kinases $(101,159-161)$.

Direct. Inhibitor of the Janus kinases $(103,159,162)$

Direct. Suppress inflammation by several mechanisms. Corticosteroids enter the cell to bind to Glucocorticoid which is located at the tip of the $\mathrm{N}$-terminal domain of the SARS-CoV-2 S protein (183)

Indirect $^{2}$

Indirect $^{2}$

Indirect $^{2}$

Indirect $^{2}$

Indirect $^{2}$

Indirect $^{2}$

Indirect $^{2}$

Indirect $^{2}$

Indirect $^{2}$

Indirect $^{2}$

Indirect $^{2}$ 
Table 2, Cont'd

receptor in the cytoplasm that translocates to the nucleus, switching off the inflammatory genes (163-167).

Dexamethasone

Direct. Suppressing inflammation by several mechanisms. Indirect $^{2}$ Corticosteroids enter the cell to bind to Glucocorticoid receptor in the cytoplasm that translocates to the nucleus, switching off the inflammatory genes $(107,168-170)$.

1. Possibily by treating the viral infection; 2 . Trough anti-inflammatory effect.

\section{DISCUSSION}

COVID-19 infection, like other infectious diseases, is associated with inflammation $(17,19,22,27)$. Growing evidence indicates the host immunologic reactions to COVID-19 is associated with hyperinflammatory responses such as cytokine storm, which play a major role in COVID-19 severity and death, and usually associated with poor disease prognosis $(21,23-25,100)$. Higher levels of inflammatory cytokines such as IL-6, IL10 , and TNF- $\alpha$ are noted in patients with severe symptoms $(23,24,26)$. Therapeutic consequences of altered cytokines expression have long been well acknowledged (171). Therefore, eradication of the virus with antiviral therapy is possibly not a sufficient strategy to reverse the side effects of the disease, mainly the damages caused by inflammation. Thus, during the disease, it is important to simultaneously fight the virus and manage the symptoms resulted from the inflammatory process. Indeed, as depicted in Table 2 all drugs used to treat COVID-19 patients have direct or indirect anti-inflammatory effects.

With regard to the effect of the reninangiotensin system, it is important to point out that although the listed drugs may be void of direct effects on the, their anti-inflammatory effect indirectly influences the system $(30,43)$.

The data on the beneficial effects of the drugs used to treat COVID-19 patients are mainly unconvincing $(60,64)$. Many reports are only clinical observations that lack the inclusion of placebo or control arms. Thus, it is unclear whether the patient would have recuperated even without the use of those drugs.
In general, Inflammation is a fundamental and protective reaction of the body to infections and injuries. Acute inflammation is a beneficial function in a short time, which results in healing and could help eradicate infections. However, chronic inflammation is a prolonged and dysregulated process, which involves active inflammation and is associated with many pathophysiological conditions such as atherosclerosis, cancer, arthritis, and autoimmune diseases $(28,29)$. Inflammation is a complex condition with great inter- and intra-patient variability (172). As such, the severity of inflammation may play a role in therapeutic outcomes. In addition, anti-inflammatory properties of drugs are not always instantaneous, thus, the optimal effect may not appear in weeks and months. The exception being the most potent anti-inflammatory class of drugs, the corticosteroids that produce anti-inflammatory responses almost immediately. Indeed, in treating patients who are afflicted with arthritis, another inflammatory disease, initial and short-term therapy with corticosteroids is common while awaiting the optimal effects of other safer antiinflammatory drugs. Interestingly, early data suggest a significant beneficial effect of corticosteroid therapy in COVID-19 patients (104-107, 173). Such a beneficial effect may not only be due to the strong anti-inflammatory effect of corticosteroids but also, the quick onset of the action of these drugs. COVID-19 infection is an invasive inflammatory affliction that needs intervention with quick therapeutic outcomes that are not expected from most anti-inflammatory drugs. Indeed, the optimal anti-inflammatory 
effect of hydroxychloroquine is reported to take weeks $(113,114,174)$, much longer than a quick multi-organ invasion of COVID-19.

The disease severity or the extent of inflammation may significantly influence the response to pharmacotherapy. This may not be a significant consideration when mere antiviral therapy is being used; but when attempting to combat inflammation associated with the viral infection, the disease severity can be of prime importance. Examples learned from other inflammatory conditions include the treatment of post-myocardial infarction patients whose survival rate depends significantly on the concentration of proinflammatory markers. Indeed, the higher the C-reactive protein concentration, the shorter will be the survival time (Figure 2) (175). It is also been reported that patients with active inflammation do not respond well to some important cardiovascular drugs (176-178). Inflammation downregulate proteins involved in the metabolism of many drugs including the blockers of calcium channel $(179,180)$, and the beta-adrenergic blocker antihypertension drugs (176). The downregulation causes high plasma concentrations of these medications. Interestingly, however, despite increased concentration, the efficacy of these drugs is reduced due to the downregulation of the receptors needed to exert effects. Controlling inflammation reverses these protein downregulations (177). The beneficial effects of drugs that interrupt angiotensin effects such as losartan (181) and valsartan (182) are not influenced by inflammation. Therefore, the influence of inflammation on response to cardiovascular drugs, and the choice of medication are important considerations in treating COVID-19 patients since the infection is associated with cardiovascular complications.

Currently, there is no specific pharmacological treatment for COVID-19 infection, thus, the therapy emphasizes the supportive care and management of the complications that are caused mainly by inflammation. In authors' opinion,

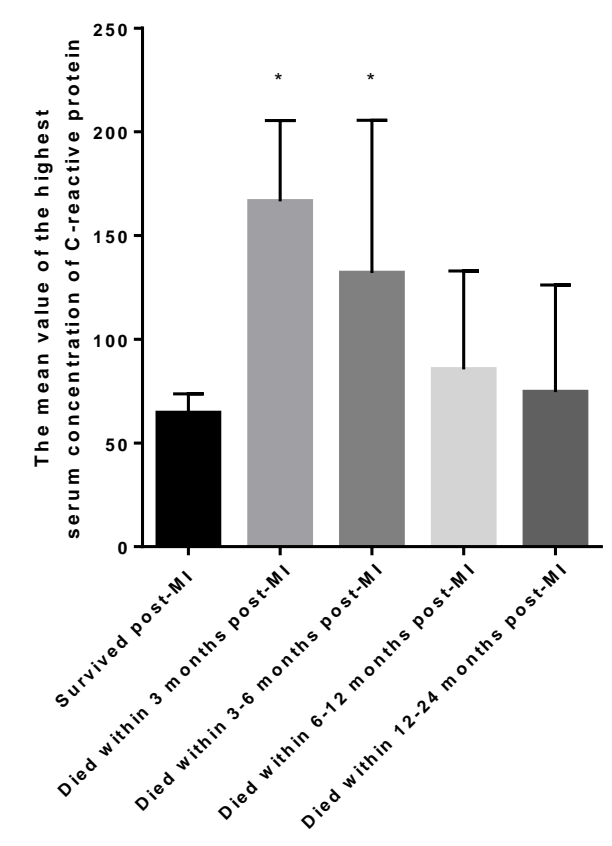

Figure 2. The effect of the extent of inflammation reflected as serum mean C-reactive protein concentration measure within $48 \mathrm{~h}$ post-myocardial infarction. Despite substantial variance, the first 6 months data were significantly different from the survived group. Adapted from reference 168. *= significant, $p<0.05$.

treatment with anti-inflammatory drugs can be beneficial in COVID-19 patients with severe hyperinflammatory conditions. However, the efficacy of this treatment still needs well-planned clinical trials. There are several ongoing clinical trials on the treatment/management of COVID 19 (https://clinicaltrials.gov/ct2/who_table). In such trials, careful attention must be paid to the duration of the treatment, the onset of beneficial effects, and the severity of the disease, otherwise, the outcomes may still remain inconclusive. Additionally, it should be considered that the ongoing research efforts worldwide continuously provide more understanding of COVID-19 pathophisiology, which in turn provides us with more efficient treatment guidelines. This is a possibility that other drugs with no anti-inflammatory properties may 
prove beneficial, although the pathophysiology may suggest otherwise.

\section{CONCLUSION}

COVID-19 severe clinical manifestation is most likely due to the host immunologic reactions. The inflammatory processes consequently damage several patient's organs and may result in severe illness and death. Controlling the inflammation quickly and long enough with appropriate antiinflammatory drugs is the key to successfully manage the disease. In treating cardiovascular complications, the influence of inflammation must be considered.

\section{CONFLICT OF INTEREST}

Authots have no conflict of interest pertaining to the content of this article.

\section{REFERENCES}

1. She J, Jiang J, Ye L, Hu L, Bai C, Song Y. 2019 novel coronavirus of pneumonia in Wuhan, China: emerging attack and management strategies. Clinical and translational medicine. 2020;9(1):19.

2. Lu R, Zhao X, Li J, Niu P, Yang B, Wu H, et al. Genomic characterisation and epidemiology of 2019 novel coronavirus: implications for virus origins and receptor binding. Lancet (London, England). 2020;395(10224):565-74.

3. Zhu N, Zhang D, Wang W, Li X, Yang B, Song $\mathrm{J}$, et al. A Novel Coronavirus from Patients with Pneumonia in China, 2019. The New England journal of medicine. 2020;382(8):727-33.

4. Guo YR, Cao QD, Hong ZS, Tan YY, Chen $\mathrm{SD}$, Jin HJ, et al. The origin, transmission and clinical therapies on coronavirus disease 2019 (COVID-19) outbreak - an update on the status. Military Medical Research. 2020;7(1):11.

5. Lee PI, Hsueh PR. Emerging threats from zoonotic coronaviruses-from SARS and MERS to 2019-nCoV. Journal of microbiology, immunology, and infection = Wei mian yu gan ran za zhi. 2020;53(3):3657.

6. Liya G, Yuguang W, Jian L, Huaiping Y, Xue $\mathrm{H}$, Jianwei $\mathrm{H}$, et al. Studies on viral pneumonia related to novel coronavirus
SARS-CoV-2, SARS-CoV, and MERSCoV: a literature review. APMIS : acta pathologica, microbiologica, et immunologica Scandinavica. 2020; 128(6):423-32.

7. Morawska L, Cao J. Airborne transmission of SARS-CoV-2: The world should face the reality. Environment international. 2020;139:105730.

8. Setti L, Passarini F, De Gennaro G, Barbieri $\mathrm{P}$, Perrone MG, Borelli M, et al. Airborne Transmission Route of COVID-19: Why 2 Meters/6 Feet of Inter-Personal Distance Could Not Be Enough. International journal of environmental research and public health. 2020;17(8).

9. Zhang W, Du RH, Li B, Zheng XS, Yang $\mathrm{XL}, \mathrm{Hu} \mathrm{B}$, et al. Molecular and serological investigation of 2019-nCoV infected patients: implication of multiple shedding routes. Emerging microbes \& infections. 2020;9(1):386-9.

10. Wang Z, Chen X, Lu Y, Chen F, Zhang W. Clinical characteristics and therapeutic procedure for four cases with 2019 novel coronavirus pneumonia receiving combined Chinese and Western medicine treatment. Bioscience trends. 2020;14(1):64-8.

11. Wang D, Hu B, Hu C, Zhu F, Liu X, Zhang $\mathrm{J}$, et al. Clinical Characteristics of 138 Hospitalized Patients With 2019 Novel Coronavirus-Infected Pneumonia in Wuhan, China. Jama. 2020;323(11):1061-9.

12. Guan WJ, Ni ZY, Hu Y, Liang WH, Ou CQ, $\mathrm{He}$ JX, et al. Clinical Characteristics of Coronavirus Disease 2019 in China. The New England journal of medicine. 2020;382(18):1708-20.

13. Liu K, Fang YY, Deng Y, Liu W, Wang MF, Ma JP, et al. Clinical characteristics of novel coronavirus cases in tertiary hospitals in Hubei Province. Chinese medical journal. 2020;133(9):1025-31.

14. Huang C, Wang Y, Li X, Ren L, Zhao J, Hu $\mathrm{Y}$, et al. Clinical features of patients infected with 2019 novel coronavirus in Wuhan, China. Lancet (London, England). 2020;395(10223):497-506.

15. Chen T, Wu D, Chen H, Yan W, Yang D, Chen G, et al. Clinical characteristics of 113 deceased patients with coronavirus disease 2019: retrospective study. BMJ (Clinical research ed). 2020;368:m1091. 
16. Zhou F, Yu T, Du R, Fan G, Liu Y, Liu Z, et al. Clinical course and risk factors for mortality of adult inpatients with COVID-19 in Wuhan, China: a retrospective cohort study. Lancet (London, England). 2020;395(10229):1054-62.

17. Lan T, Chang L, Wu L, Yuan YF. IL-6 Plays a Crucial Role in HBV Infection. Journal of clinical and translational hepatology. 2015;3(4):271-6.

18. Velazquez-Salinas L, Verdugo-Rodriguez A, Rodriguez LL, Borca MV. The Role of Interleukin 6 During Viral Infections. Frontiers in microbiology. 2019;10:1057.

19. Wu W, Dietze KK, Gibbert K, Lang KS, Trilling M, Yan H, et al. TLR ligand induced IL- 6 counter-regulates the anti-viral CD8(+) $\mathrm{T}$ cell response during an acute retrovirus infection. Scientific reports. 2015;5:10501.

20. Chen G, Wu D, Guo W, Cao Y, Huang D, Wang H, et al. Clinical and immunological features of severe and moderate coronavirus disease 2019. The Journal of clinical investigation. 2020;130(5):2620-9.

21. Mehta P, McAuley DF, Brown M, Sanchez E, Tattersall RS, Manson JJ. COVID-19: consider cytokine storm syndromes and immunosuppression. Lancet (London, England). 2020;395(10229):1033-4.

22. García LF. Immune Response, Inflammation, and the Clinical Spectrum of COVID-19. Frontiers in immunology. 2020;11:1441.

23. Hu B, Huang S, Yin L. The cytokine storm and COVID-19. Journal of medical virology. 2020.

24. Coperchini F, Chiovato L, Croce L, Magri F, Rotondi M. The cytokine storm in COVID19: An overview of the involvement of the chemokine/chemokine-receptor system. Cytokine \& growth factor reviews. 2020;53:25-32.

25. Abdin SM, Elgendy SM, Alyammahi SK, Alhamad DW, Omar HA. Tackling the cytokine storm in COVID-19, challenges and hopes. Life sciences. 2020;257:118054.

26. Lippi G, Plebani M. Laboratory abnormalities in patients with COVID-2019 infection. Clinical chemistry and laboratory medicine. 2020;58(7):1131-4.

27. Merad M, Martin JC. Pathological inflammation in patients with COVID-19: a key role for monocytes and macrophages.
Nature reviews Immunology. 2020;20(6):355-62.

28. Weiss U. Inflammation. Nature. 2008;454(7203):427.

29. Kuprash DV, Nedospasov SA. Molecular and Cellular Mechanisms of Inflammation. Biochemistry Biokhimiia. 2016;81(11):1237-9.

30. Hanafy S, El-Kadi AO, Jamali F. Effect of inflammation on molecular targets and drug transporters. Journal of pharmacy \& pharmaceutical sciences : a publication of the Canadian Society for Pharmaceutical Sciences, Societe canadienne des sciences pharmaceutiques. 2012;15(3):361-75.

31. Li G, Fan Y, Lai Y, Han T, Li Z, Zhou P, et al. Coronavirus infections and immune responses. Journal of medical virology. 2020;92(4):424-32.

32. Long B, Brady WJ, Koyfman A, Gottlieb M. Cardiovascular complications in COVID19. The American journal of emergency medicine. 2020;38(7):1504-7.

33. Driggin E, Madhavan MV, Bikdeli B, Chuich T, Laracy J, Biondi-Zoccai G, et al. Cardiovascular Considerations for Patients, Health Care Workers, and Health Systems During the COVID-19 Pandemic. Journal of the American College of Cardiology. 2020;75(18):2352-71.

34. Guo T, Fan Y, Chen M, Wu X, Zhang L, He $\mathrm{T}$, et al. Cardiovascular Implications of Fatal Outcomes of Patients With Coronavirus Disease 2019 (COVID-19). JAMA cardiology. 2020;5(7):1-8.

35. Tang N, Li D, Wang X, Sun Z. Abnormal coagulation parameters are associated with poor prognosis in patients with novel coronavirus pneumonia. Journal of thrombosis and haemostasis : JTH. 2020;18(4):844-7.

36. Suba Z. Prevention and therapy of COVID19 via exogenous estrogen treatment for both male and female patients. Journal of pharmacy \& pharmaceutical sciences : a publication of the Canadian Society for Pharmaceutical Sciences, Societe canadienne des sciences pharmaceutiques. 2020;23(1):75-85.

37. Bourgonje AR, Abdulle AE, Timens W, Hillebrands JL, Navis GJ, Gordijn SJ, et al. Angiotensin-converting enzyme 2 (ACE2), SARS-CoV-2 and the pathophysiology of 
coronavirus disease 2019 (COVID-19). The Journal of pathology. 2020.

38. Li W, Moore MJ, Vasilieva N, Sui J, Wong SK, Berne MA, et al. Angiotensinconverting enzyme 2 is a functional receptor for the SARS coronavirus. Nature. 2003;426(6965):450-4.

39. Letko M, Marzi A, Munster V. Functional assessment of cell entry and receptor usage for SARS-CoV-2 and other lineage B betacoronaviruses. Nature microbiology. 2020;5(4):562-9.

40. South AM, Shaltout HA, Washburn LK, Hendricks AS, Diz DI, Chappell MC. Fetal programming and the angiotensin-(1-7) axis: a review of the experimental and clinical data. Clinical science (London, England : 1979). 2019;133(1):55-74.

41. Donoghue M, Hsieh F, Baronas E, Godbout K, Gosselin M, Stagliano N, et al. A novel angiotensin-converting enzyme-related carboxypeptidase (ACE2) converts angiotensin $\mathrm{I}$ to angiotensin 1-9. Circulation research. 2000;87(5):E1-9.

42. $\mathrm{Wu} \mathrm{CH}$, Mohammadmoradi S, Chen JZ, Sawada H, Daugherty A, Lu HS. ReninAngiotensin System and Cardiovascular Functions. Arteriosclerosis, thrombosis, and vascular biology. 2018;38(7):e108-e16.

43. Asghar W, Aghazadeh-Habashi A, Jamali F. Cardiovascular effect of inflammation and nonsteroidal anti-inflammatory drugs on renin-angiotensin system in experimental arthritis. Inflammopharmacology. 2017.

44. Hanafy S, Tavasoli M, Jamali F. Inflammation alters angiotensin converting enzymes (ACE and ACE-2) balance in rat heart. Inflammation. 2011;34(6):609-13.

45. Franco R, Rivas-Santisteban R, SerranoMarín J, Rodríguez-Pérez AI, LabandeiraGarcía JL, Navarro G. SARS-CoV-2 as a Factor to Disbalance the Renin-Angiotensin System: A Suspect in the Case of Exacerbated IL-6 Production. Journal of immunology (Baltimore, Md : 1950). 2020.

46. Md Insiat Islam R. Current Drugs with Potential for Treatment of COVID-19: A Literature Review. Journal of pharmacy \& pharmaceutical sciences : a publication of the Canadian Society for Pharmaceutical Sciences, Societe canadienne des sciences pharmaceutiques. 2020;23(1):58-64.
47. Şimşek Yavuz S, Ünal S. Antiviral treatment of COVID-19. Turkish journal of medical sciences. 2020;50(Si-1):611-9.

48. McKee DL, Sternberg A, Stange U, Laufer S, Naujokat C. Candidate drugs against SARS-CoV-2 and COVID-19. Pharmacological research. 2020;157:104859.

49. Grein J, Ohmagari N, Shin D, Diaz G, Asperges E, Castagna A, et al. Compassionate Use of Remdesivir for Patients with Severe Covid-19. The New England journal of medicine. 2020;382(24):2327-36.

50. Wang M, Cao R, Zhang L, Yang X, Liu J, $\mathrm{Xu} \mathrm{M}$, et al. Remdesivir and chloroquine effectively inhibit the recently emerged novel coronavirus (2019-nCoV) in vitro. Cell research. 2020;30(3):269-71.

51. Lim J, Jeon S, Shin HY, Kim MJ, Seong YM, Lee WJ, et al. Case of the Index Patient Who Caused Tertiary Transmission of COVID-19 Infection in Korea: the Application of Lopinavir/Ritonavir for the Treatment of COVID-19 Infected Pneumonia Monitored by Quantitative RTPCR. Journal of Korean medical science. 2020;35(6):e79.

52. Li Y, Xie Z, Lin W, Cai W, Wen C, Guan Y, et al. Efficacy and Safety of Lopinavir/Ritonavir or Arbidol in Adult Patients with Mild/Moderate COVID-19: An Exploratory Randomized Controlled Trial. Med. 2020.

53. Cai Q, Yang M, Liu D, Chen J, Shu D, Xia $\mathrm{J}$, et al. Experimental Treatment with Favipiravir for COVID-19: An Open-Label Control Study. Engineering (Beijing, China). 2020.

54. Magro G. COVID-19: Review on latest available drugs and therapies against SARSCoV-2. Coagulation and inflammation cross-talking. Virus research. 2020;286:198070.

55. Franzetti $M$, Pozzetti U, Carugati $M$, Pandolfo A, Molteni C, Faccioli P, et al. Interleukin-1 receptor antagonist anakinra in association with remdesivir in severe coronavirus disease 2019: A case report. International journal of infectious diseases : IJID : official publication of the International Society for Infectious Diseases. 2020;97:215-8. 
56. Lu CC, Chen MY, Lee WS, Chang YL. Potential therapeutic agents against COVID19: What we know so far. Journal of the Chinese Medical Association : JCMA. 2020;83(6):534-6.

57. Saber-Ayad M, Saleh MA, Abu-Gharbieh E. The Rationale for Potential Pharmacotherapy of COVID-19. Pharmaceuticals (Basel, Switzerland). 2020;13(5).

58. Wu R, Wang L, Kuo HD, Shannar A, Peter $\mathrm{R}$, Chou PJ, et al. An Update on Current Therapeutic Drugs Treating COVID-19. Current pharmacology reports. 2020:1-15.

59. Biggest COVID-19 trial tests repurposed drugs first. Nature biotechnology. 2020;38(5):510.

60. Ford N, Vitoria M, Rangaraj A, Norris SL, Calmy A, Doherty M. Systematic review of the efficacy and safety of antiretroviral drugs against SARS, MERS or COVID-19: initial assessment. Journal of the International AIDS Society. 2020;23(4):e25489.

61. Hung IF, Lung KC, Tso EY, Liu R, Chung TW, Chu MY, et al. Triple combination of interferon beta-1b, lopinavir-ritonavir, and ribavirin in the treatment of patients admitted to hospital with COVID-19: an open-label, randomised, phase 2 trial. Lancet (London, England). 2020;395(10238):1695704.

62. De Meyer S, Bojkova D, Cinatl J, Van Damme E, Buyck C, Van Loock M, et al. Lack of antiviral activity of darunavir against SARS-CoV-2. International journal of infectious diseases : IJID : official publication of the International Society for Infectious Diseases. 2020;97:7-10.

63. Ferner RE, Aronson JK. Chloroquine and hydroxychloroquine in covid-19. BMJ (Clinical research ed). 2020;369:m1432.

64. Meo SA, Klonoff DC, Akram J. Efficacy of chloroquine and hydroxychloroquine in the treatment of COVID-19. European review for medical and pharmacological sciences. 2020;24(8):4539-47.

65. Gautret P, Lagier JC, Parola P, Hoang VT, Meddeb L, Mailhe $\mathrm{M}$, et al. Hydroxychloroquine and azithromycin as a treatment of COVID-19: results of an openlabel non-randomized clinical trial. International journal of antimicrobial agents. 2020:105949.
66. Tang W, Cao Z, Han M, Wang Z, Chen J, Sun $W$, et al. Hydroxychloroquine in patients with mainly mild to moderate coronavirus disease 2019: open label, randomised controlled trial. BMJ (Clinical research ed). 2020;369:m1849.

67. Liu J, Cao R, Xu M, Wang X, Zhang H, Hu $\mathrm{H}$, et al. Hydroxychloroquine, a less toxic derivative of chloroquine, is effective in inhibiting SARS-CoV-2 infection in vitro. Cell discovery. 2020;6:16.

68. Geleris J, Sun Y, Platt J, Zucker J, Baldwin M, Hripcsak G, et al. Observational Study of Hydroxychloroquine in Hospitalized Patients with Covid-19. The New England journal of medicine. 2020;382(25):2411-8.

69. Magagnoli J, Narendran S, Pereira F, Cummings T, Hardin JW, Sutton SS, et al. Outcomes of hydroxychloroquine usage in United States veterans hospitalized with Covid-19. medRxiv : the preprint server for health sciences. 2020.

70. Meyerowitz EA, Vannier AGL, Friesen MGN, Schoenfeld S, Gelfand JA, Callahan $\mathrm{MV}$, et al. Rethinking the role of hydroxychloroquine in the treatment of COVID-19. FASEB journal : official publication of the Federation of American Societies for Experimental Biology. 2020;34(5):6027-37.

71. Arshad S, Kilgore P, Chaudhry ZS, Jacobsen G, Wang DD, Huitsing K, et al. Treatment with hydroxychloroquine, azithromycin, and combination in patients hospitalized with COVID-19. International journal of infectious diseases : IJID : official publication of the International Society for Infectious Diseases. 2020;97:396-403.

72. Corral P, Corral G, Diaz R. Colchicine and COVID-19. Journal of clinical pharmacology. 2020;60(8):978.

73. Deftereos SG, Siasos G, Giannopoulos G, Vrachatis DA, Angelidis C, Giotaki SG, et al. The Greek study in the effects of colchicine in COvid-19 complications prevention (GRECCO-19 study): Rationale and study design. Hellenic journal of cardiology : $\mathrm{HJC}=$ Hellenike kardiologike epitheorese. 2020;61(1):42-5.

74. Mansouri N, Marjani M, Tabarsi P, von Garnier C, Mansouri D. Successful Treatment of Covid-19 Associated Cytokine Release Syndrome with Colchicine. A Case 
Report and Review of Literature. Immunological investigations. 2020:1-7.

75. Pani A, Lauriola M, Romandini A, Scaglione F. Macrolides and viral infections: focus on azithromycin in COVID-19 pathology. International journal of antimicrobial agents. 2020:106053.

76. Hughes JH, Sweeney K, Ahadieh S, Ouellet D. Predictions of Systemic, Intracellular, and Lung Concentrations of Azithromycin With Different Dosing Regimens Used in COVID-19 Clinical Trials. CPT: pharmacometrics \& systems pharmacology. 2020.

77. Cavalli G, De Luca G, Campochiaro C, Della-Torre E, Ripa M, Canetti D, et al. Interleukin-1 blockade with high-dose anakinra in patients with COVID-19, acute respiratory distress syndrome, and hyperinflammation: a retrospective cohort study. The Lancet Rheumatology. 2020;2(6):e325-e31.

78. Aouba A, Baldolli A, Geffray L, Verdon R, Bergot E, Martin-Silva N, et al. Targeting the inflammatory cascade with anakinra in moderate to severe COVID-19 pneumonia: case series. Annals of the rheumatic diseases. 2020.

79. Ucciferri C, Auricchio A, Di Nicola M, Potere N, Abbate A, Cipollone F, et al. Canakinumab in a subgroup of patients with COVID-19. The Lancet Rheumatology. 2020.

80. Antwi-Amoabeng D, Kanji Z, Ford B, Beutler BD, Riddle MS, Siddiqui F. Clinical outcomes in COVID-19 patients treated with tocilizumab: An individual patient data systematic review. Journal of medical virology. 2020.

81. Xu X, Han M, Li T, Sun W, Wang D, Fu B, et al. Effective treatment of severe COVID19 patients with tocilizumab. Proceedings of the National Academy of Sciences of the United States of America. 2020;117(20):10970-5.

82. Morena V, Milazzo L, Oreni L, Bestetti G, Fossali T, Bassoli C, et al. Off-label use of tocilizumab for the treatment of SARSCoV-2 pneumonia in Milan, Italy. European journal of internal medicine. 2020;76:36-42.

83. Rojas-Marte GR, Khalid M, Mukhtar O, Hashmi AT, Waheed MA, Ehrlich S, et al. Outcomes in Patients with Severe COVID19 Disease Treated with Tocilizumab - A
Case- Controlled Study. QJM : monthly journal of the Association of Physicians. 2020.

84. Alattar R, Ibrahim TBH, Shaar SH, Abdalla S, Shukri K, Daghfal JN, et al. Tocilizumab for the treatment of severe coronavirus disease 2019. Journal of medical virology. 2020.

85. Toniati P, Piva S, Cattalini M, Garrafa E, Regola F, Castelli F, et al. Tocilizumab for the treatment of severe COVID-19 pneumonia with hyperinflammatory syndrome and acute respiratory failure: A single center study of 100 patients in Brescia, Italy. Autoimmunity reviews. 2020;19(7):102568.

86. Price CC, Altice FL, Shyr Y, Koff A, Pischel L, Goshua G, et al. Tocilizumab Treatment for Cytokine Release Syndrome in Hospitalized COVID-19 Patients: Survival and Clinical Outcomes. Chest. 2020.

87. Palanques-Pastor T, López-Briz E, Poveda Andrés JL. Involvement of interleukin 6 in SARS-CoV-2 infection: siltuximab as a therapeutic option against COVID-19. European journal of hospital pharmacy : science and practice. 2020.

88. Crisafulli S, Isgrò V, La Corte L, Atzeni F, Trifirò G. Potential Role of Anti-interleukin (IL)-6 Drugs in the Treatment of COVID19: Rationale, Clinical Evidence and Risks. BioDrugs : clinical immunotherapeutics, biopharmaceuticals and gene therapy. 2020:1-8.

89. Benucci M, Giannasi G, Cecchini P, Gobbi FL, Damiani A, Grossi V, et al. COVID-19 pneumonia treated with Sarilumab: A clinical series of eight patients. Journal of medical virology. 2020.

90. Della-Torre E, Campochiaro C, Cavalli G, De Luca G, Napolitano A, La Marca S, et al. Interleukin-6 blockade with sarilumab in severe COVID-19 pneumonia with systemic hyperinflammation: an open-label cohort study. Annals of the rheumatic diseases. 2020.

91. Gemcioglu E, Davutoglu M, Ozdemir EE, Erden A. Are type 1 interferons treatment in Multiple Sclerosis as a potential therapy against COVID-19? Multiple sclerosis and related disorders. 2020;42:102196.

92. Zhou Q, Chen V, Shannon CP, Wei XS, Xiang $X$, Wang $X$, et al. Interferon- $\alpha 2 b$ 
Treatment for COVID-19. Frontiers in immunology. 2020;11:1061.

93. Dastan F, Nadji SA, Saffaei A, Marjani M, Moniri A, Jamaati $\mathrm{H}$, et al. Subcutaneous administration of interferon beta-1a for COVID-19: A non-controlled prospective trial. International immunopharmacology. 2020;85:106688.

94. Sallard E, Lescure FX, Yazdanpanah Y, Mentre F, Peiffer-Smadja N. Type 1 interferons as a potential treatment against COVID-19. Antiviral research. 2020;178:104791.

95. Richardson PJ, Corbellino M, Stebbing J. Baricitinib for COVID-19: a suitable treatment? - Authors' reply. The Lancet Infectious diseases. 2020.

96. Cantini F, Niccoli L, Matarrese D, Nicastri E, Stobbione P, Goletti D. Baricitinib therapy in COVID-19: A pilot study on safety and clinical impact. The Journal of infection. 2020.

97. Cj Jorgensen S, Ly Tse C, Burry L, Dresser LD. Baricitinib: A review of pharmacology, safety and emerging clinical experience in COVID-19. Pharmacotherapy. 2020.

98. Cantini F, Niccoli L, Nannini C, Matarrese $D$, Natale MED, Lotti $P$, et al. Beneficial impact of Baricitinib in COVID-19 moderate pneumonia; multicentre study. The Journal of infection. 2020.

99. Seif F, Aazami H, Khoshmirsafa M, Kamali M, Mohsenzadegan M, Pornour M, et al. JAK Inhibition as a New Treatment Strategy for Patients with COVID-19. International archives of allergy and immunology. 2020;181(6):467-75.

100. Yeleswaram S, Smith P, Burn T, Covington M, Juvekar A, Li Y, et al. Inhibition of cytokine signaling by ruxolitinib and implications for COVID-19 treatment. Clinical immunology (Orlando, Fla). 2020;218:108517.

101. La Rosée F, Bremer HC, Gehrke I, Kehr A, Hochhaus A, Birndt S, et al. The Janus kinase 1/2 inhibitor ruxolitinib in COVID19 with severe systemic hyperinflammation. Leukemia. 2020;34(7):1805-15.

102. Goker Bagca B, Biray Avci C. The potential of JAK/STAT pathway inhibition by ruxolitinib in the treatment of COVID-19. Cytokine \& growth factor reviews. 2020.

103. Wu D, Yang XO. TH17 responses in cytokine storm of COVID-19: An emerging target of JAK2 inhibitor Fedratinib. Journal of microbiology, immunology, and infection $=$ Wei mian yu gan ran za zhi. 2020;53(3):368-70.

104. Fadel R, Morrison AR, Vahia A, Smith ZR, Chaudhry Z, Bhargava P, et al. Early Short Course Corticosteroids in Hospitalized Patients with COVID-19. Clinical infectious diseases : an official publication of the Infectious Diseases Society of America. 2020.

105. Qin YY, Zhou YH, Lu YQ, Sun F, Yang S, Harypursat V, et al. Effectiveness of glucocorticoid therapy in patients with severe coronavirus disease 2019: protocol of a randomized controlled trial. Chinese medical journal. 2020;133(9):1080-6.

106. So C, Ro S, Murakami M, Imai R, Jinta T. High-dose, short-term corticosteroids for ARDS caused by COVID-19: a case series. Respirology case reports. 2020;8(6):e00596.

107. Johnson RM, Vinetz JM. Dexamethasone in the management of covid -19. BMJ (Clinical research ed). 2020;370:m2648.

108. Selvaraj V, Dapaah-Afriyie K, Finn A, Flanigan TP. Short-Term Dexamethasone in Sars-CoV-2 Patients. Rhode Island medical journal (2013). 2020;103(6):39-43.

109. Bird NL, Olson MR, Hurt AC, Oshansky CM, Oh DY, Reading PC, et al. Oseltamivir Prophylaxis Reduces Inflammation and Facilitates Establishment of Cross-Strain Protective T Cell Memory to Influenza Viruses. PloS one. 2015;10(6):e0129768.

110. Zuwala K, Riber CF, Løvschall KB, Andersen AHF, Sørensen L, Gajda P, et al. Macromolecular prodrugs of ribavirin: Polymer backbone defines blood safety, drug release, and efficacy of antiinflammatory effects. Journal of controlled release : official journal of the Controlled Release Society. 2018;275:53-66.

111. van den Borne BE, Dijkmans BA, de Rooij $\mathrm{HH}$, le Cessie S, Verweij CL. Chloroquine and hydroxychloroquine equally affect tumor necrosis factor-alpha, interleukin 6 , and interferon-gamma production by peripheral blood mononuclear cells. The Journal of rheumatology. 1997;24(1):55-60.

112. Clark P, Casas E, Tugwell P, Medina C, Gheno C, Tenorio G, et al. Hydroxychloroquine compared with placebo in rheumatoid arthritis. A 
randomized controlled trial. Annals of internal medicine. 1993;119(11):1067-71.

113. Kingsbury SR, Tharmanathan P, Adamson J, Arden NK, Birrell F, Cockayne S, et al. Hydroxychloroquine effectiveness in reducing symptoms of hand osteoarthritis (HERO): study protocol for a randomized controlled trial. Trials. 2013;14:64.

114. Detert J, Klaus P, Listing J, Höhne-Zimmer $\mathrm{V}$, Braun $\mathrm{T}$, Wassenberg $\mathrm{S}$, et al. Hydroxychloroquine in patients with inflammatory and erosive osteoarthritis of the hands (OA TREAT): study protocol for a randomized controlled trial. Trials. 2014;15:412.

115. Kovarsky J. Hydroxychloroquine in rheumatoid arthritis. Arthritis and rheumatism. 1984;27(11):1315-6.

116. Ponticelli C, Moroni G. Hydroxychloroquine in systemic lupus erythematosus (SLE). Expert opinion on drug safety. 2017;16(3):411-9.

117. Goldman FD, Gilman AL, Hollenback C, Kato RM, Premack BA, Rawlings DJ. Hydroxychloroquine inhibits calcium signals in $\mathrm{T}$ cells: a new mechanism to explain its immunomodulatory properties. Blood. 2000;95(11):3460-6.

118. Sacre K, Criswell LA, McCune JM. Hydroxychloroquine is associated with impaired interferon-alpha and tumor necrosis factor-alpha production by plasmacytoid dendritic cells in systemic lupus erythematosus. Arthritis research \& therapy. 2012;14(3):R155.

119. Costedoat-Chalumeau N, Dunogué B, Morel $\mathrm{N}$, Le Guern V, Guettrot-Imbert G. Hydroxychloroquine: a multifaceted treatment in lupus. Presse medicale (Paris, France : 1983). 2014;43(6 Pt 2):e167-80.

120. Abdulaziz N, Shah AR, McCune WJ. Hydroxychloroquine: balancing the need to maintain therapeutic levels with ocular safety: an update. Current opinion in rheumatology. 2018;30(3):249-55.

121. Kyburz D, Brentano F, Gay S. Mode of action of hydroxychloroquine in RAevidence of an inhibitory effect on toll-like receptor signaling. Nature clinical practice Rheumatology. 2006;2(9):458-9.

122. $\mathrm{Hu} \mathrm{C}, \mathrm{Lu} \mathrm{L}$, Wan JP, Wen C. The Pharmacological Mechanisms and Therapeutic Activities of Hydroxychloroquine in Rheumatic and
Related Diseases. Current medicinal chemistry. 2017;24(20):2241-9.

123. Sperber K, Quraishi H, Kalb TH, Panja A, Stecher V, Mayer L. Selective regulation of cytokine secretion by hydroxychloroquine: inhibition of interleukin 1 alpha (IL-1-alpha) and IL-6 in human monocytes and T cells. The Journal of rheumatology. 1993;20(5):803-8.

124. Rainsford KD, Parke AL, Clifford-Rashotte M, Kean WF. Therapy and pharmacological properties of hydroxychloroquine and chloroquine in treatment of systemic lupus erythematosus, rheumatoid arthritis and related diseases. Inflammopharmacology. 2015;23(5):231-69.

125. Angelidis C, Kotsialou Z, Kossyvakis C, Vrettou AR, Zacharoulis A, Kolokathis F, et al. Colchicine Pharmacokinetics and Mechanism of Action. Current pharmaceutical design. 2018;24(6):659-63.

126. Dalbeth N, Lauterio TJ, Wolfe HR. Mechanism of action of colchicine in the treatment of gout. Clinical therapeutics. 2014;36(10):1465-79.

127. Liantinioti G, Argyris AA, Protogerou AD, Vlachoyiannopoulos P. The Role of Colchicine in the Treatment of Autoinflammatory Diseases. Current pharmaceutical design. 2018;24(6):690-4.

128. Ianaro A, Ialenti A, Maffia P, Sautebin L, Rombolà L, Carnuccio R, et al. Antiinflammatory activity of macrolide antibiotics. The Journal of pharmacology and experimental therapeutics. 2000;292(1):156-63.

129. Banjanac M, Munić Kos V, Nujić K, Vrančić M, Belamarić D, Crnković S, et al. Anti-inflammatory mechanism of action of azithromycin in LPS-stimulated J774A.1 cells. Pharmacological research. 2012;66(4):357-62.

130. Lin SJ, Kuo ML, Hsiao HS, Lee PT. Azithromycin modulates immune response of human monocyte-derived dendritic cells and $\mathrm{CD} 4(+) \mathrm{T}$ cells. International immunopharmacology. 2016;40:318-26.

131. Haydar D, Cory TJ, Birket SE, Murphy BS, Pennypacker KR, Sinai AP, et al. Azithromycin Polarizes Macrophages to an M2 Phenotype via Inhibition of the STAT1 and NF- $\kappa \mathrm{B}$ Signaling Pathways. Journal of immunology (Baltimore, Md : 1950). 2019;203(4):1021-30. 
132. Gensel JC, Kopper TJ, Zhang B, Orr MB, Bailey WM. Predictive screening of M1 and M2 macrophages reveals the immunomodulatory effectiveness of post spinal cord injury azithromycin treatment. Scientific reports. 2017;7:40144.

133. Ramírez J, Cañete JD. Anakinra for the treatment of rheumatoid arthritis: a safety evaluation. Expert opinion on drug safety. 2018;17(7):727-32.

134. Thompson PL, Nidorf SM. Antiinflammatory therapy with canakinumab for atherosclerotic disease: lessons from the CANTOS trial. Journal of thoracic disease. 2018;10(2):695-8.

135. Everett BM, Donath MY, Pradhan AD, Thuren T, Pais P, Nicolau JC, et al. AntiInflammatory Therapy With Canakinumab for the Prevention and Management of Diabetes. Journal of the American College of Cardiology. 2018;71(21):2392-401.

136. Everett BM, Cornel JH, Lainscak M, Anker $\mathrm{SD}$, Abbate A, Thuren $\mathrm{T}$, et al. AntiInflammatory Therapy With Canakinumab for the Prevention of Hospitalization for Heart Failure. Circulation. 2019;139(10):1289-99.

137. Crossman D, Rothman AMK. Interleukin-1 beta inhibition with canakinumab and reducing lung cancer-subset analysis of the canakinumab anti-inflammatory thrombosis outcome study trial (CANTOS). Journal of thoracic disease. 2018;10(Suppl 26):S3084s7.

138. Le RQ, Li L, Yuan W, Shord SS, Nie L, Habtemariam BA, et al. FDA Approval Summary: Tocilizumab for Treatment of Chimeric Antigen Receptor T Cell-Induced Severe or Life-Threatening Cytokine Release Syndrome. The oncologist. 2018;23(8):943-7.

139. Tanaka T, Narazaki M, Kishimoto T. IL-6 in inflammation, immunity, and disease. Cold Spring Harbor perspectives in biology. 2014;6(10):a016295.

140. Rossi JF, Lu ZY, Jourdan M, Klein B. Interleukin- 6 as a therapeutic target. Clinical cancer research : an official journal of the American Association for Cancer Research. 2015;21(6):1248-57.

141. Rubbert-Roth A, Furst DE, Nebesky JM, Jin A, Berber E. A Review of Recent Advances Using Tocilizumab in the Treatment of
Rheumatic Diseases. Rheumatology and therapy. 2018;5(1):21-42.

142. Yao X, Huang J, Zhong H, Shen N, Faggioni R, Fung M, et al. Targeting interleukin-6 in inflammatory autoimmune diseases and cancers. Pharmacology \& therapeutics. 2014;141(2):125-39.

143. Casper C, Chaturvedi S, Munshi N, Wong R, Qi M, Schaffer M, et al. Analysis of Inflammatory and Anemia-Related Biomarkers in a Randomized, Double-Blind, Placebo-Controlled Study of Siltuximab (Anti-IL6 Monoclonal Antibody) in Patients With Multicentric Castleman Disease. Clinical cancer research : an official journal of the American Association for Cancer Research. 2015;21(19):4294-304.

144. Burmester GR, Lin Y, Patel R, van Adelsberg J, Mangan EK, Graham NM, et al. Efficacy and safety of sarilumab monotherapy versus adalimumab monotherapy for the treatment of patients with active rheumatoid arthritis (MONARCH): a randomised, double-blind, parallel-group phase III trial. Annals of the rheumatic diseases. 2017;76(5):840-7.

145. Lee EB. A review of sarilumab for the treatment of rheumatoid arthritis. Immunotherapy. 2018;10(1):57-65.

146. Lamb YN, Deeks ED. Sarilumab: A Review in Moderate to Severe Rheumatoid Arthritis. Drugs. 2018;78(9):929-40.

147. Samuel CE. Antiviral actions of interferons. Clinical microbiology reviews. 2001;14(4):778-809, table of contents.

148. Faraji F, Hashemi M, Ghiasabadi A, Davoudian S, Talaie A, Ganji A, et al. Combination therapy with interferon beta-1a and sesame oil in multiple sclerosis. Complementary therapies in medicine. 2019;45:275-9.

149. Nikolaus S, Rutgeerts P, Fedorak R, Steinhart AH, Wild GE, Theuer D, et al. Interferon beta-1a in ulcerative colitis: a placebo controlled, randomised, dose escalating study. Gut. 2003;52(9):1286-90.

150. Ghasami K, Faraji F, Fazeli M, Ghazavi A, Mosayebi G. Interferon $\beta-1 \mathrm{a}$ and Atorvastatin in the Treatment of Multiple Sclerosis. Iranian journal of immunology : IJI. 2016;13(1):16-26.

151. Lin FC, Young HA. Interferons: Success in anti-viral immunotherapy. Cytokine \& growth factor reviews. 2014;25(4):369-76. 
152. Khademi M, Wallström E, Andersson M, Piehl F, Di Marco R, Olsson T. Reduction of both pro- and anti-inflammatory cytokines after 6 months of interferon beta-1a treatment of multiple sclerosis. Journal of neuroimmunology. 2000;103(2):202-10.

153. Ramakrishna R, Manoharan A. Sustained long-term remissions with weekly interferon maintenance therapy in hairy cell leukemia. Asia-Pacific journal of clinical oncology. 2010;6(3):210-2.

154. Huang Y, Blatt LM, Taylor MW. Type 1 interferon as an antiinflammatory agent: inhibition of lipopolysaccharide-induced interleukin-1 beta and induction of interleukin-1 receptor antagonist. Journal of interferon \& cytokine research : the official journal of the International Society for Interferon and Cytokine Research. 1995;15(4):317-21.

155. Wallace DJ, Furie RA, Tanaka Y, Kalunian KC, Mosca M, Petri MA, et al. Baricitinib for systemic lupus erythematosus: a doubleblind, randomised, placebo-controlled, phase 2 trial. Lancet (London, England). 2018;392(10143):222-31.

156. Taylor PC, Keystone EC, van der Heijde D, Weinblatt ME, Del Carmen Morales L, Reyes Gonzaga J, et al. Baricitinib versus Placebo or Adalimumab in Rheumatoid Arthritis. The New England journal of medicine. 2017;376(7):652-62.

157. Al-Salama ZT, Scott LJ. Baricitinib: A Review in Rheumatoid Arthritis. Drugs. 2018;78(7):761-72.

158. Ancuța C, Pomîrleanu C, Mihailov C, Chirieac R, Ancuța E, Iordache C, et al. Efficacy of baricitinib on periodontal inflammation in patients with rheumatoid arthritis. Joint bone spine. 2020;87(3):235-9.

159. Roskoski R, Jr. Janus kinase (JAK) inhibitors in the treatment of inflammatory and neoplastic diseases. Pharmacological research. 2016;111:784-803.

160. Yang AY, Liu JQ, Cai YN, Fang MY, Yang $\mathrm{L}$, Chen M, et al. [The anti-proliferative and anti-inflammatory mechanisms of JAK1 inhibitor SHR0302 versus Ruxolitinib in SET2 cell line and primary cells]. Zhonghua xue ye xue za zhi = Zhonghua xueyexue zazhi. 2019;40(12):1003-7.

161. Elli EM, Baratè C, Mendicino F, Palandri F, Palumbo GA. Mechanisms Underlying the Anti-inflammatory and Immunosuppressive
Activity of Ruxolitinib. Frontiers in oncology. 2019;9:1186.

162. Fedratinib Becomes New Option in Myelofibrosis. Cancer discovery. 2019;9(10):1332.

163. Rakonczay Z, Jr., Duda E, Kaszaki J, Iványi B, Boros I, Lonovics J, et al. The antiinflammatory effect of methylprednisolone occurs down-stream of nuclear factorkappaB DNA binding in acute pancreatitis. European journal of pharmacology. 2003;464(2-3):217-27.

164. Barnes PJ. Corticosteroid effects on cell signalling. The European respiratory journal. 2006;27(2):413-26.

165. Haroon M, O'Gradaigh D. Efficacy and safety of combining intra-articular methylprednisolone and anti-TNF agent to achieve prolonged remission in patients with recurrent inflammatory monoarthritis. Joint bone spine. 2010;77(3):232-4.

166. Barnes PJ. How corticosteroids control inflammation: Quintiles Prize Lecture 2005. British journal of pharmacology. 2006;148(3):245-54.

167. Sellebjerg F. Methylprednisolone treatment, immune activation, and intrathecal inflammation in multiple sclerosis. Danish medical bulletin. 2004;51(2):167-83.

168. El Azab SR, Rosseel PM, de Lange JJ, Groeneveld AB, van Strik R, van Wijk EM, et al. Dexamethasone decreases the pro- to anti-inflammatory cytokine ratio during cardiac surgery. British journal of anaesthesia. 2002;88(4):496-501.

169. Dey R, Bishayi B. Dexamethasone exhibits its anti-inflammatory effects in S. aureus induced microglial inflammation via modulating TLR-2 and glucocorticoid receptor expression. International immunopharmacology. 2019;75:105806.

170. Liu X, De Scheerder I, Desmet W. Dexamethasone-eluting stent: an antiinflammatory approach to inhibit coronary restenosis. Expert review of cardiovascular therapy. 2004;2(5):653-60.

171. Kulmatycki KM, Jamali F. Therapeutic relevance of altered cytokine expression. Cytokine. 2001;14(1):1-10.

172. Kulmatycki KM, Jamali F. Drug disease interactions: role of inflammatory mediators in disease and variability in drug response. Journal of pharmacy \& pharmaceutical sciences : a publication of the Canadian 
Society for Pharmaceutical Sciences, Societe canadienne des sciences pharmaceutiques. 2005;8(3):602-25.

173. Kolilekas L, Loverdos K, Giannakaki S, Vlassi L, Levounets A, Zervas E, et al. Can steroids reverse the severe COVID-19 induced "cytokine storm"? Journal of medical virology. 2020.

174. Tett S, Cutler D, Day R. Antimalarials in rheumatic diseases. Bailliere's clinical rheumatology. 1990;4(3):467-89.

175. Pietilä KO, Harmoinen AP, Jokiniitty J, Pasternack AI. Serum C-reactive protein concentration in acute myocardial infarction and its relationship to mortality during 24 months of follow-up in patients under thrombolytic treatment. European heart journal. 1996;17(9):1345-9.

176. Guirguis MS, Jamali F. Disease-drug interaction: Reduced response to propranolol despite increased concentration in the rat with inflammation. Journal of pharmaceutical sciences. 2003;92(5):107784.

177. Ling S, Lewanczuk RZ, Russell AS, Ihejirika B, Jamali F. Influence of controlled rheumatoid arthritis on the action and disposition of verapamil: focus on infliximab. Journal of clinical pharmacology. 2009;49(3):301-11.

178. Mayo PR, Skeith K, Russell AS, Jamali F. Decreased dromotropic response to verapamil despite pronounced increased drug concentration in rheumatoid arthritis. British journal of clinical pharmacology. 2000;50(6):605-13.

179. Gilzad-Kohan MH, Jamali F. Glucosamine and adjuvant arthritis: a pharmacokinetic and pharmacodynamic study. European journal of pharmaceutical sciences : official journal of the European Federation for Pharmaceutical Sciences. 2012;47(2):38793.

180. Sanaee F, Clements JD, Waugh AW, Fedorak RN, Lewanczuk R, Jamali F. Drugdisease interaction: Crohn's disease elevates verapamil plasma concentrations but reduces response to the drug proportional to disease activity. British journal of clinical pharmacology. 2011;72(5):787-97.

181. Daneshtalab N, Lewanczuk RZ, Russell AS, Jamali F. Drug-disease interactions: losartan effect is not downregulated by rheumatoid arthritis. Journal of clinical pharmacology. 2006;46(11):1344-55.

182. Daneshtalab N, Lewanczuk RZ, Russell A, Jamali F. Rheumatoid arthritis does not reduce the pharmacodynamic response to valsartan. Journal of clinical pharmacology. 2004;44(3):245-52.

183. Fantini J, Di Scala C, Chahinian H, Yahi N. Structural and molecular modelling studies reveal a new mechanism of action of chloroquine and hydroxychloroquine against SARS-CoV-2 infection. Int $\mathbf{J}$ Antimicrob Agents. 2020;55(5):105960. 